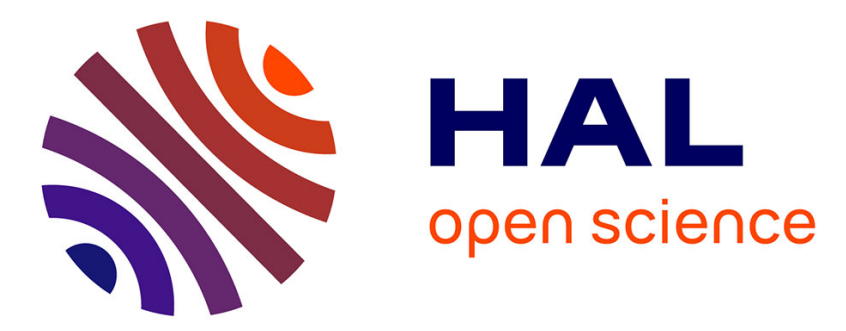

\title{
A new test for cleaning efficiency assessment of cleaners for hard surfaces
}

Marie-Élise Chateau, Laurence Galet, Yannick Soudais, Jacques Fages

\section{To cite this version:}

Marie-Élise Chateau, Laurence Galet, Yannick Soudais, Jacques Fages. A new test for cleaning efficiency assessment of cleaners for hard surfaces. Journal of Surfactants and Detergents, 2004, 7 (4), pp.355-362. 10.1007/s11743-004-0318-6 . hal-01593339

\section{HAL Id: hal-01593339 \\ https://hal.science/hal-01593339}

Submitted on 7 Feb 2018

HAL is a multi-disciplinary open access archive for the deposit and dissemination of scientific research documents, whether they are published or not. The documents may come from teaching and research institutions in France or abroad, or from public or private research centers.
L'archive ouverte pluridisciplinaire HAL, est destinée au dépôt et à la diffusion de documents scientifiques de niveau recherche, publiés ou non, émanant des établissements d'enseignement et de recherche français ou étrangers, des laboratoires publics ou privés. 


\title{
A New Test for Cleaning Efficiency Assessment of Cleaners for Hard Surfaces
}

\author{
Marie-Elise Chateau, ${ }^{a}$, Laurence Galet ${ }^{b, t}$, Yannick Soudais ${ }^{b}$, and Jacques Fages ${ }^{b}$ \\ à La Vigie Company, 30130 Pont Saint Esprit, France, and 'bChemical Engineering Laboratory for Particulate Solids, Unité Mixte de \\ Recherche (UMR) 2392 Centre Nationale de Recherche Scientifique (CNRS), Ėcole des Mines d'Albi-Carmaux, Albi, France
}

\begin{abstract}
A new test was developed to assess the efficiency of no-wiping hard-surface cleaning. The test allows cleaner comparisons according to their ability to remove greasy soils. The chosen approach minimizes the mechanical forces applied while cleaning so that the interactions between a detergent solution and the soil to be removed can be characterized. For this, immersion cleaning was chosen, with coated stainless steel as substrate and pigmented oils as the model soil. Several parameters were studied in defined ranges using the Experimental Design method and systematic comparisons. The test shows high reliability on degreasing assessments and is therefore especially suited to optimization of nonionic surfactant mixes. The originality of the test lies in the possibility of keeping a visual trace of the cleaned substrate appearance by imprinting it on a piece of paper. The validation of the test leads to corroboration of several practical observations. Temperature and agitation play a major role in cleaning efficiency. Detergent solution concentration is a more relevant parameter then $\mathrm{pH}$. Sodium carbonate is shown to have a higher buffering effect than pentahydrated sodium metasilicate. The test is easy to set up, highly sensitive, and can be adapted to solve the problems encountered by formulators of detergent cleaners, such as screening the best ethoxylated fatty alcohol mix for better degreasing properties.

Paper no. S1383 in JSD 7, 355-362 (October 2004).
\end{abstract}

KEY WORDS: Builder, detergency, hard-surface cleaning, organic soil, particles, surfactant.

Clcaning is the removal of soil attached to or encrusted on a substrate. The objective is to return the surface to the appearance it had before being soiled. Cleanliness of hard surfaces is a major factor for achieving good adhesion or coating. The physicochemical basis of detergency by surfactants in aqueous solutions was first described by Lawrence (1) in the 1960s. It gained practical interest in the 1990s. At that time, cleaning temperatures became lower in Europe owing to energy-saving concerns for textile washing, and the emergence of new nonionic surfactants having lower cloud points allowed better cleaning mechanism optimization (2).

\footnotetext{
To whom correspondence should be addressed at Chemical Engineering Laboratory for Particulate Solids, UMR 2392 CNRS, École des Mines d'Nbi-Carmatux, 81013 Albi, France.

E-mail: Laurence.Galeterenstimac. it

Abbreviations: EO, chylene oxide: "f. French unit for hard water measuresnents; RH. relative humiditw; STPP, sodium tripolyphosphatt.
}

Metal degreasing with organic solvents had to be replaced because of environmental, safety, and health concerns in the beginning of the 1990 s (3). The integrated circuit industry dealt with ever smaller parts and increasing capacities, and soil particles became an important source of defects (4). In other areas, such as the food industry, legislation became stringent, and fouling meant a decrease in operating efficiency and product quality (5). For all these reasons, aqueous cleaning has been explored more and more during the last decade.

The mechanism of oily soil removal by aqueous surfactants has been clescribed as a succession of three steps (6):

- Transport of the surfactants within the aqueous phase onto the substrate and soil surface;

- Penetration of surfactant molecules into the soil, leading to a rolling-up for liquid soils, and to a decrease in adhesion energy for solid soils;

- Transport and dispersion of the dislocated soil in the cleaning bath.

The use of liquids also facilitates particle removal: Liquids lower the van der Waals attraction, and the force exerted by their surface tension is opposed to the adhesion forces between particles and substrate (4).

No standard method is available for assessing the efficiency of nowiping hard-surface cleaning, but many tests have been developed with well-defined substrates and soil. In 1996 Prieto et al. (7) described a spray cabinet with controlled pressure of spray cleaning, and several immersion tests have been mentioned in the literature. Cleaning efficiency has been assessed using numerous analytical methods. The purpose was either to improve paint cleanability by coating formulation, or to gain better insight into cleaning physicochemical processes. The aim of the present work was to develop a test (i) that was easy to set up, (ii) that allowed both simple and sensitive cleanliness analyses for hard-surface cleaner comparisons, and (iii) that allowed formulation optimization.

\section{EXPERIMENTAL PROCEDURES}

Producls and instrumentation. (i) Rane molerials for deteryent formulations. A nonionic ethoxylated fatty alcohol and a 
cationic ammonium salt were selected as surfactants, i.e., an alcohol ethoxylate [C9-C1 1, 5.5 ethylene oxide (EO)] and alkyl polyglycol ether ammonium methyl sulfate, respectively. Two different alkaline systems were selected: sodium tripolyphosphate (STPP) and sodium pentahydrated metasilicate, and STPP and sodium carbonate. The water used was $25^{\circ} \mathrm{f}$ of hardness (French unit for hard water measurements), equivalent to $14^{\circ} \mathrm{GH}$ (German unit) and $250 \mathrm{ppm}$ (American unit), obtained by dissolution of $\mathrm{MgCl}_{2}$ and $\mathrm{CaCl}_{2}$ salts in deionized water.

(ii) Raw materials for soil formulation. The model soil was prepared with peanut oil $(9.5 \%)$, sunflower oil $(19.0 \%)$, diesel engine oil $15 W 40(28.5 \%)$, kaolin $(36.9 \%)$, graphice $(3.4 \%)$, and black and yellow iron oxide ( 1.9 and $0.8 \%$, respectively).

(iii) Detergent solution analyses. A pH meter and a conductance meter were used to analyze the detergent solution before and after cleaning. A drying oven was used to age the soil. A bath with a thermostat was used during the cleaning test. A high-precision balance $\left(10^{-4} \mathrm{~g}\right)$ was used to formulate and to weigh the plate samples.

(iv) The plntes. Circular plates of stainless steel were coated with a polyurethane white paint designed for car bodies. These plates were $75 \mathrm{~mm}$ in diameter, $2 \mathrm{~mm}$ thick, and had a hole $8 \mathrm{~cm}$ in diameter drilled out through the middle. During the experiment, the plate was screwed onto a rotation shaft (Fig. 1). A mixer with digital indicator of the speed in revolutions per minute (rpm) was used for a controlled rotation of the plate.

Description of the iest. (i) Soil formulation, application, and aging. The oils are nixed together and then the powdered materials are added one by one. The mixture is then homogenized for $10 \mathrm{~min}$. A clean, dry circular plate that had previously been weighed on the precision balance $\left(m_{0}\right)$ is fixed on the extremity of the shaft, and slow rotation starts $(50 \mathrm{rpm})$. The soil is then applied and homogeneously spread on the surface, which is rotated at a speed of $500 \mathrm{rpm}$ for $15 \mathrm{~s}$. According to this proceclure, $0.3 \mathrm{~g}$ of pigmented oily soil covers the plate. Plates that are to be aged are placed in a drying oven after weighing $\left(m_{1}\right)$, and the soiled plates unclergo seven cycles from $45^{\circ} \mathrm{C}, 55 \%$ relative humidity (RH), to $6^{\circ} \mathrm{C}, 80 \% \mathrm{RH}$, for $24 \mathrm{~h}$ (Fig. 2).

(ii) Formulation of the detergent solution. The composition of the surfactant mixture is two-thirds nonionic and onethird cationic $\langle w / w\rangle$, and the ratio of surfactant to builder is $3: 10(w / w)$ The raw materials are mixed together in a bowl and then dissolved in $1 \mathrm{~L}$ of water $\left(25^{\circ} \mathrm{H}\right)$. Once the operating temperature of $25^{\circ} \mathrm{C}$ has been reached, $\mathrm{pH}$ and conductivity (in $\mathrm{mS} / \mathrm{cm}$ ) of the cleaning solution are measured. The same measurements are made on the bath right after cleaning.

(iii) Cleaning test protocol. A soiled plate is fixed on the shaft, with the soil on the bottom face. The plate is dipped in to the detergent solution, held at $25^{\circ} \mathrm{C}$ in a 2-L beaker, to a depth of $5 \mathrm{~cm}$ (total depth of $8 \mathrm{~cm}$ ) (Fig. 1). Soaking time is two-thirds of the total cleaning time. The remaining onethird is the washing time, during which the plate is put in rotation. After cleaning, the plate is rinsed for $1 \mathrm{~min}$ in fresh water at the same speed. The plate is then left for more than $12 \mathrm{~h}$ at room temperature to let the excess water evaporate.

(iv) Cleaning efficiency assessment: gravimetric results and imprint. The amount of soil removed by cleaning can be determined by

$$
\text { \%removed soil }=\frac{\left(m_{1}-m_{2}\right)}{\left(m_{1}-m_{0}\right)} \times 100
$$

where $m_{0}$ is the mass of the plate before soiling, $m_{1}$ is the mass of the plate after soiling, and $m_{0}$ is the mass of the plate after cleaning with the tested cleaner. With the described soil, it is then possible to keep a visual trace of the pattern result by imprinting it on a piece of paper by applying pressure.

Experimental design, $2^{3}$. In the present work, an experimental design having three factors with two levels was performed to optimize the cleaning test. Results were characterized according to analysis of variance theory (8). Table 1 shows the experimental matrix of the eight trials to be run,

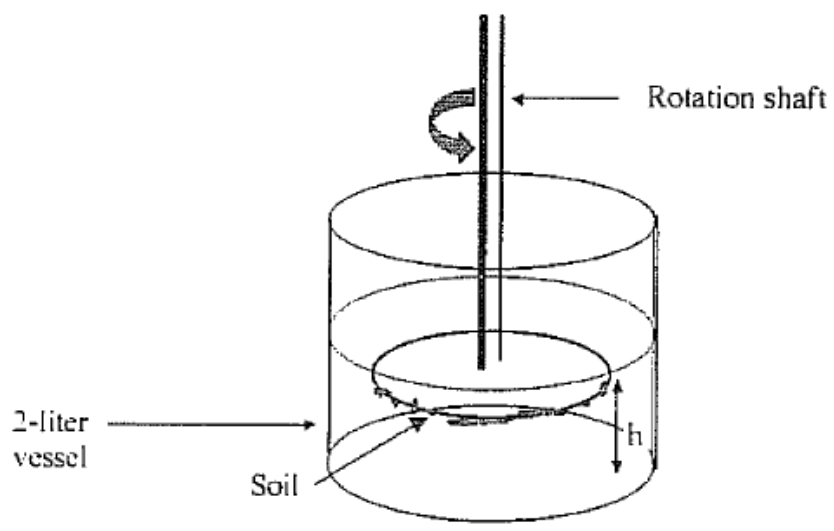

FIG. 1. Scheme of the detergency immersion test. 


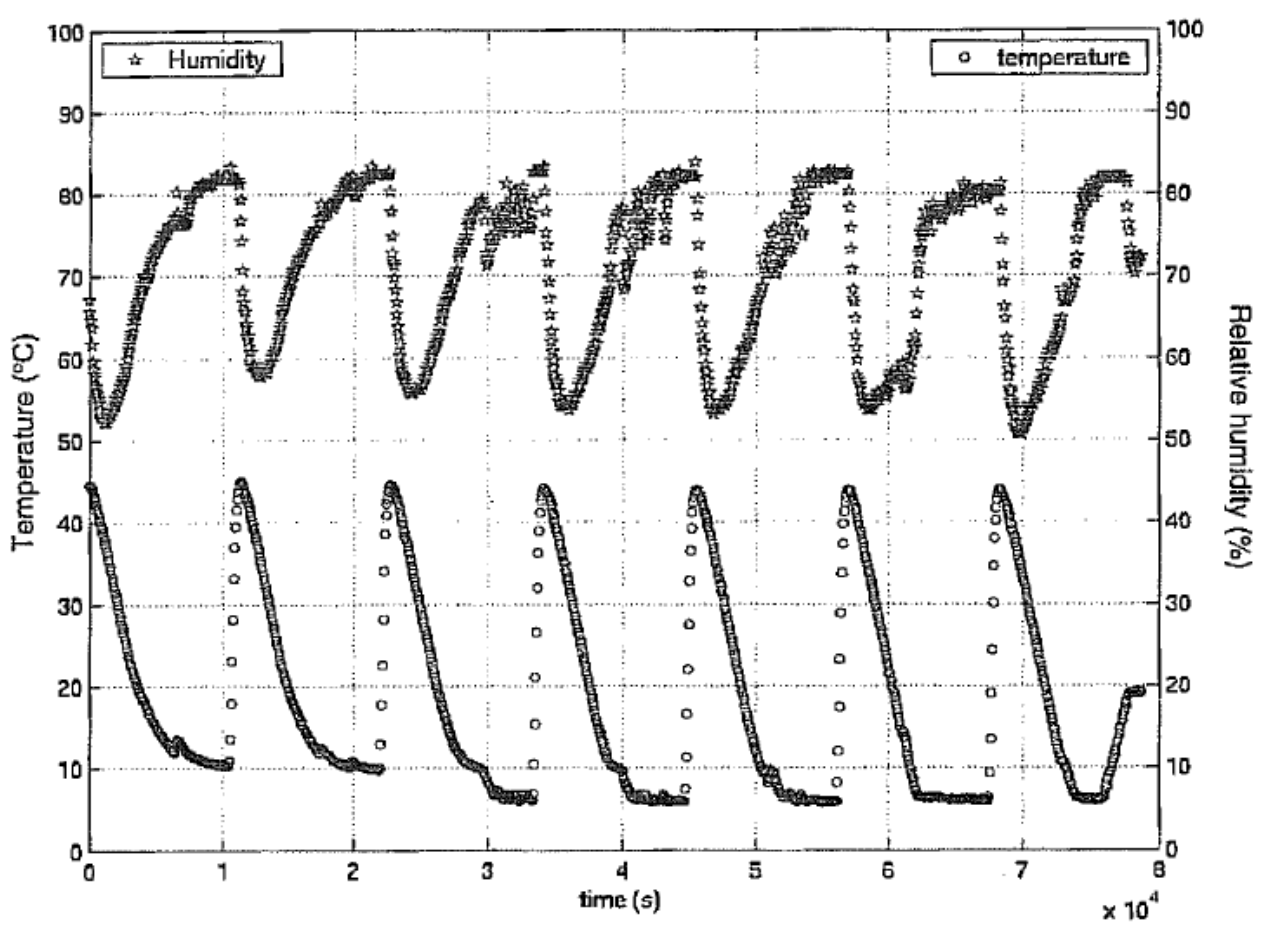

FIG. 2. Cycles of soil aging undergone by the soiled plates.

TABLE 1

Experimental Design Matrix

\begin{tabular}{|c|c|c|c|c|c|c|}
\hline $\begin{array}{l}\text { Trial } \\
\text { no. }\end{array}$ & Factor I & Factor 2 & Factor 3 & $\begin{array}{c}\text { Response } \\
1\end{array}$ & $\begin{array}{c}\text { Response } \\
2\end{array}$ & $\begin{array}{l}\text { Mean } \\
\text { value }\end{array}$ \\
\hline 1 & - & - & - & $y_{1}$ & $\dot{y}_{1}$ & $r_{1}=\frac{\left(y_{1}+\dot{y}_{1}\right)}{2}$ \\
\hline 2 & - & - & + & $y_{2}$ & $\dot{y}_{2}$ & $\bar{y}_{2}=\frac{\left(y_{1}+\dot{y}_{2}\right)}{2}$ \\
\hline 3 & - & + & - & $y_{1}$ & $\dot{y}_{y}$ & $\bar{y}_{1}=\frac{\left(y_{3}+\dot{y}_{3}\right)}{2}$ \\
\hline 4 & - & + & + & $y_{4}$ & $\dot{y}_{4}$ & $\bar{y}_{4}=\frac{\left(y_{4}+\dot{y}_{4}\right)}{2}$ \\
\hline 5 & + & - & - & $y_{s}$ & $\dot{y}_{5}$ & $\bar{y}_{5}=\frac{\left(y_{5}+\dot{y}_{s}\right)}{2}$ \\
\hline 6 & + & - & + & $y_{4}^{\prime \prime}$ & $\dot{y}_{b}$ & $\bar{y}_{6}=\frac{\left(y_{b}+\dot{y}_{6}\right)}{2}$ \\
\hline 7 & $\div$ & + & - & $y$ & $\dot{y}_{2}$ & $\bar{y}_{1}=\frac{\left(y_{\mathrm{\gamma}}+\hat{y}\right)}{2}$ \\
\hline 8 & + & + & + & $y_{8}$ & $\dot{y}_{k}$ & $\bar{y}_{s}=\frac{\left(y_{k}+\bar{y}_{k}\right)}{2}$ \\
\hline & & & & & & $\bar{y}$ \\
\hline
\end{tabular}


each factor taking upper $(+)$ and lower $(-)$ levels. The selected response was measured twice. The analysis of variance matrix was built according to the analysis of variance (8) (Table 2).

\section{RESULTS AND DISCUSSION}

Detergent composition. (i) Surfactants. Nonionic alcohol ethoxylates are the most frequently used surfactants in studies on cleaning efficiency $(9,10)$. They are usually low foaming, they are more efficient at lower concentrations and at lower temperatures than anionic surfactants, and they allow a greater flexibility in the formula (11). A judicious choice of the mix of homologs with different ethoxylated chain length and fatty alcohol chain is a determinant of success. Alcohol ethoxylates have low water-solubility and therefore represent the most active species in the greasy soil removal mechanism: Short-chain EO molecules possess an even higher tendency to penetrate the soil (12), and short-chain hydrocarbonated molecules (C9-C11) help soil removal due to their solvent-like properties (7). Optimization of the hydrophilic-lipophilic balance is important so that surfactants do not excessively partition into the oil phase during cleaning. The cationic surfactant was introduced in the stuclied formulation for its hydrotropic properties: It solubilizes the water-insoluble compounds. In contrast with the other surfactants, cationics adsorb with their heads oriented toward soil surfaces, which are usually negatively charged. The soil therefore maintains its hy- drophobic character, although cationic surfactants are rarely used alone (11).

(ii) Builders. The role of builders in cleaner formulation is to adjust the $\mathrm{pH}$ and to act as a reserve of alkalinity. They neutralize $\mathrm{Ca}^{2+}$ and $\mathrm{Mg}^{2+}$ ions in hard water, improve surfactant effectiveness, and initiate early surfactant aggregation. STPP is the most effective builder, has high charge density, and reacts synergistically with surfactants. It can neutralize acidic soils and is safe on soft metals (lead, tin, copper, and zinc) and aluminum. Sodium carbonate is an excellent $\mathrm{pH}$ controller, buffer, and reserve of alkalinity, but it forms precipitates with hard water ions and should be used with other complexants. Silicates provide a reserve of alkalinity, and they inhibit alkaline attack on soft metals $(13,14)$. Formula $B$ (with sodium carbonate) has a higher conductivity than formula A (7.64 instead of $6.74 \mathrm{mS} / \mathrm{cm}$ for $9 \% \mathrm{w} / \mathrm{w}$ and 13.15 instead of $12.32 \mathrm{mS} / \mathrm{cm}$ for $1.8 \%$ $w / w)$. The reduction in concluctivity and $\mathrm{pH}$ after cleaning is lower for formula $B$ than for formula $A$. The difference is 0.13 and $0.61 \mathrm{mS} / \mathrm{cm}$, and 0.03 and $0.05 \mathrm{pH}$ units for formula $A$, whereas it is 0.04 and $0.09 \mathrm{mS} / \mathrm{cm}$ and $0.01 \mathrm{pH}$ unit for formula $B$ (Table 3). These observations are in accordance with the fact that sodium carbonate is less alkaline than metasilicate, but has higher buffering properties and represents a good reserve of alkalinity.

Discrussion on the cleaning test protocol. (i) Substrate, soil, soil application, and aging. Polyurethane-coated stainless steel was chosen for its high surface energy and low roughness, which emphasize the physicochemical interactions (15) as

TABLE 2

Analysis of Variance Table ${ }^{a}$

\begin{tabular}{|c|c|c|c|c|c|}
\hline & Effect $\left(E_{i}\right)$ & $\begin{array}{l}\text { Least square } \\
\text { function (LSF) }\end{array}$ & $\begin{array}{l}\text { Degrees of } \\
\text { freedom } \\
\left({ }^{\circ} f\right)\end{array}$ & Variance $\left(S^{2}\right)$ & $\begin{array}{c}F_{\text {calculated }} \\
\left(F_{\text {cal }}\right)\end{array}$ \\
\hline Factor $i$ & $E_{i}=\frac{\sum_{i=1}^{n}\left(y_{i}+\dot{y}_{i}\right)}{n}$ & $\mathrm{LSF}_{j}=E_{i}^{2} \times n$ & ${ }^{\circ} f_{i}=k_{i}-1$ & $S_{i}^{2}=\frac{\mathrm{LSF}_{i}}{f_{i}}$ & $F_{\text {cal }}=\frac{S_{i}^{2}}{S_{\text {ras }}^{2}}$ \\
\hline Residual & & $\begin{array}{l}\operatorname{LSF}_{t a s}= \\
\sum_{s=1}^{n}\left[\left(y_{1}-\bar{y}_{l}\right)^{2}+\left(\dot{y}_{1}-\bar{y}_{i}\right)^{2}\right]\end{array}$ & $\begin{array}{l}{ }^{\circ} f_{\mathrm{res}}=n-\Pi k_{1} \\
=\Pi k_{i}(r-1)\end{array}$ & $S_{\text {tes }}^{z}=\frac{L_{S F}}{{ }^{a} f_{\text {res }}}$ & \\
\hline Total & & $\begin{array}{l}\operatorname{LSF}_{1 \mathrm{it}}= \\
\sum_{i=1}^{n}\left[\left(y_{1}-\bar{y}\right)^{2}+\left(\dot{y}_{1}-\bar{y}\right)^{2}\right]\end{array}$ & ${ }^{\circ} f_{\mathrm{tol}}=\Pi k_{\mathrm{r}} r-1$ & & \\
\hline
\end{tabular}

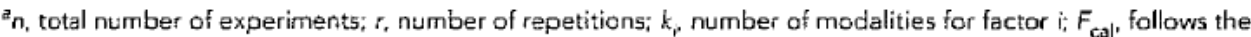
Fisher-Snedecor law, and has to be compared to the theoretical Fisher value, $F_{\text {treo }}$ that can be found in tables for a specified risk (for exanple, of 0.05): $F_{\text {the }}=F_{i k, 1, \pi k,-1 .}$. If $F_{c a t}>F_{\text {thes }}$ the effect of the considered factor $i$ is significant. $F_{\text {eal }}$ for an interaction between factors is to compare to $F_{\text {theo }}=F_{\left.\left(11: k_{i}-1\right), \Pi h ;, r-1\right)}$. 
TABLE 3

$\mathrm{pH}$ and Conductivity Results, Initially and After Cleaning

\begin{tabular}{lllll} 
& \multicolumn{2}{c}{ Formula A } & \multicolumn{2}{c}{ Formula B } \\
& Initial pH & $\mathrm{pH}$ after cleaning & Initial pH & pH after cleaning \\
\hline $0.9 \mathrm{wt} \%$ & $11.96 \pm 0.02$ & $11.93 \pm 0.01$ & $11.11 \pm 0.01$ & $11.10 \pm 0.01$ \\
$1.8 \mathrm{wt} \%$ & $12.17 \pm 0.04$ & $12.12 \pm 0.02$ & $11.15 \pm 0.01$ & $11.14 \pm 0.01$ \\
\cline { 2 - 5 } & $\begin{array}{l}\text { Initial conductivity } \\
\text { (mS/cm) }\end{array}$ & $\begin{array}{l}\text { Conductivity after } \\
\text { cleaning }(\mathrm{mS} / \mathrm{cm})\end{array}$ & $\begin{array}{l}\text { Initial conductivity } \\
(\mathrm{mS} / \mathrm{cm})\end{array}$ & $\begin{array}{l}\text { Conductivity after } \\
\text { cleaning (mS/cm) }\end{array}$ \\
\cline { 2 - 5 } $0.9 \mathrm{wt} \%$ & $6.74 \pm 0.13$ & $6.61 \pm 0.05$ & $7.64 \pm 0.03$ & $7.60 \pm 0.05$ \\
$1.8 \mathrm{wt} \%$ & $12.32 \pm 0.40$ & $11.71 \pm 06$ & $13.15 \pm 0.03$ & $13.06 \pm 0.07$ \\
\hline
\end{tabular}

adhesion forces and minimize physically entrapped particles. The white color makes the visual observations easier. Finally, polyurethane-coated stainless steel is still used for car bodies, and is a good example of a surface that is important industrially.

Two different kinds of soil must be distinguished: the organic film type (hydrocarbons) and inorganic particles. The first interferes with subsequent adhesion, whereas the second impedes work involving small dimensions such as integrated circuit devices (16). In the literature, several authors have used pigmented greasy soils $(2,10,14,17)$. These were applied onto the substrate in a homogeneous layer (9), and they could be aged according to special procedures $(7,18)$. The present work evaluates a mix of both kinds of soil. The organic oils [fatty oils, mineral naphthenic, and paraffinic oil (13) ] in this study are difficult or moderately difficult to remove (19). The particles are introduced to give higher viscosity and dark coloration to the model soil, rather than to study the removal of fine particles. The results showed that aging of the soiled plates had as much of an influence on soil removal as varying the temperature from 30 down to $25^{\circ} \mathrm{C}$.

(ii) Cleaning efficiency assessment. The focus is put on greasy soils. The white towel test and the tape pull test are the easiest tests to use to detect whether any oily soils remain on the surface $(16,19,20)$. Analytical techniques can be used for a quantitative assessment, and the ones most commonly found in the literature are as follows:

- Surface energy characterization, to detect remaining oily films via contact angle measurements, and water break test, a quality control test to confirm the lack of surface contamination) $(17,21,22)$.

- Gravimetric test, by weighing $(7,9,12,20)$

- Reflectometry and colorimetry measurements $(10,15,18)$; ellipsometry $(5,11)$

Highly sensitive apparatus can be used as well, such as atomic force microscopy (15), Fourier transform infrared attenuated total reflectance spectroscopy (12), and Auger/electron spectroscopy for chemical analysis or scanning electron microscopy $(14,16)$.

All the techniques mentioned above are performed on cleaned surfaces. Analysis of the cleaning bath could give information on cleaner activity as well using high-performance liquid chromatography (12), chemical oxygen demand, and filtration (9).

Weighing the plates before and after soiling and clean-

TABLE 4

The Three Chosen Factors and Their Upper (+) and Lower $(-)$ Levels

\begin{tabular}{|c|c|c|c|}
\hline Factor & $\begin{array}{c}\text { Bath temperature }\left({ }^{\circ} \mathrm{C}\right) \\
T\end{array}$ & $\begin{array}{c}\text { Aging in drying oven } \\
A\end{array}$ & $\begin{array}{c}\text { Agitation speed (rpm) } \\
S\end{array}$ \\
\hline Level - & 25 & No & 150 \\
Level + & 35 & Yes & 250 \\
\hline
\end{tabular}


TABLE 5

Effect Matrix and Least Squares Function Values ${ }^{a}$

\begin{tabular}{|c|c|c|c|c|c|c|c|c|c|}
\hline Trial & I & Factor 1 & Factor 2 & Factor 3 & $\begin{array}{c}\text { Int. } \\
12\end{array}$ & $\begin{array}{c}\text { Int. } \\
13\end{array}$ & $\begin{array}{c}\text { Int. } \\
23\end{array}$ & $\begin{array}{c}\text { Int. } \\
123\end{array}$ & $\begin{array}{c}\text { Mean value } \\
\text { (of 2 responses) }\end{array}$ \\
\hline 1 & + & - & - & - & + & + & + & - & 83.8 \\
\hline 2 & + & - & - & + & + & - & - & + & 93.2 \\
\hline 3 & + & - & + & - & - & + & - & + & 66.8 \\
\hline 4 & + & - & + & + & - & - & + & - & 87.8 \\
\hline 5 & + & + & - & - & - & - & + & + & 92.4 \\
\hline 6 & + & + & - & + & - & + & - & - & 98.2 \\
\hline 7 & + & + & + & - & + & - & - & - & 81.1 \\
\hline 8 & + & + & + & + & + & + & + & + & 93.7 \\
\hline Effecl & & 4.232 & -4.779 & 6.097 & 0.826 & -1.502 & 2.301 & -0.608 & Global mean value $=$ \\
\hline LSF & & 286.6 & 365.4 & 594.8 & 10.9 & 36.1 & 84.7 & 5.9 & 87.1 \\
\hline
\end{tabular}

Int., interaction between factors; for other abbreviations see Tables 2 and 3 .

TABLE 6

Analysis of Variance Matrix with Theoretical Fisher $(1,8)$, and Risk $=0.05$

\begin{tabular}{|c|c|c|c|c|c|c|}
\hline Variance & LSF & ${ }^{\circ f}$ & $\overline{S^{2}}$ & $F_{\text {(calculated) }}$ & $F_{\text {(theoretical) }}$ & Significant \\
\hline $\mathrm{T}$ & 286.5 & 1.00 & 286.5 & 26.36 & 5.32 & Yes \\
\hline$A$ & 365.5 & 1.00 & 365.5 & 33.62 & 5.32 & Yes \\
\hline$S$ & 594.7 & 1.00 & 594.7 & 54.71 & 5.32 & Yes \\
\hline TA & 10.9 & 1.00 & 10.9 & 1.00 & 5.32 & No \\
\hline TS & 36.1 & 1.00 & 36.1 & 3.32 & 5.32 & No \\
\hline AS & 84.7 & 1.00 & 84.7 & 7.80 & 5.32 & Yes \\
\hline TAS & 5.9 & 1.00 & 5.9 & 0.55 & 5.32 & No \\
\hline Residual response & 86.96 & 8.00 & 10.87 & & & \\
\hline Total & 1471.31 & 15.00 & 98.09 & & & \\
\hline
\end{tabular}

ing is simple and leads to high reproducibility with the chosen soil and substrate: Under our conditions the standard deviation was $1.5 \%$ calculated on 12 experiments repeated two or three times. The originality of our methocl lies in the possibility of keeping an imprint of the result. Indeed, the pattern of the cleaned surface is easily and precisely reproduced on al white paper by applying pressure.

Experimental design resulls. This first part of the experimental clesign was carried out with a detergent solution (formula $A$ ) for the purpose of defining the optimal physical parameters shown in Table 4 . The matrix of effects and least squares function values, and the analysis of variance matrix are shown in Tables 5 and 6 . The closen response is the percentage of soil removal.

The responses, in percentages, presented here are the mean values of two replicates, except for trials 7 and 8 . The reproducibility for Trials $1-6$ was good, with al standard deviation of $3.4 \%$. Therefore, it was considered reasonable to 
TABLE 7

Results of Removed Soil Percentage with Time and Concentration at $150 \mathrm{rpm}$

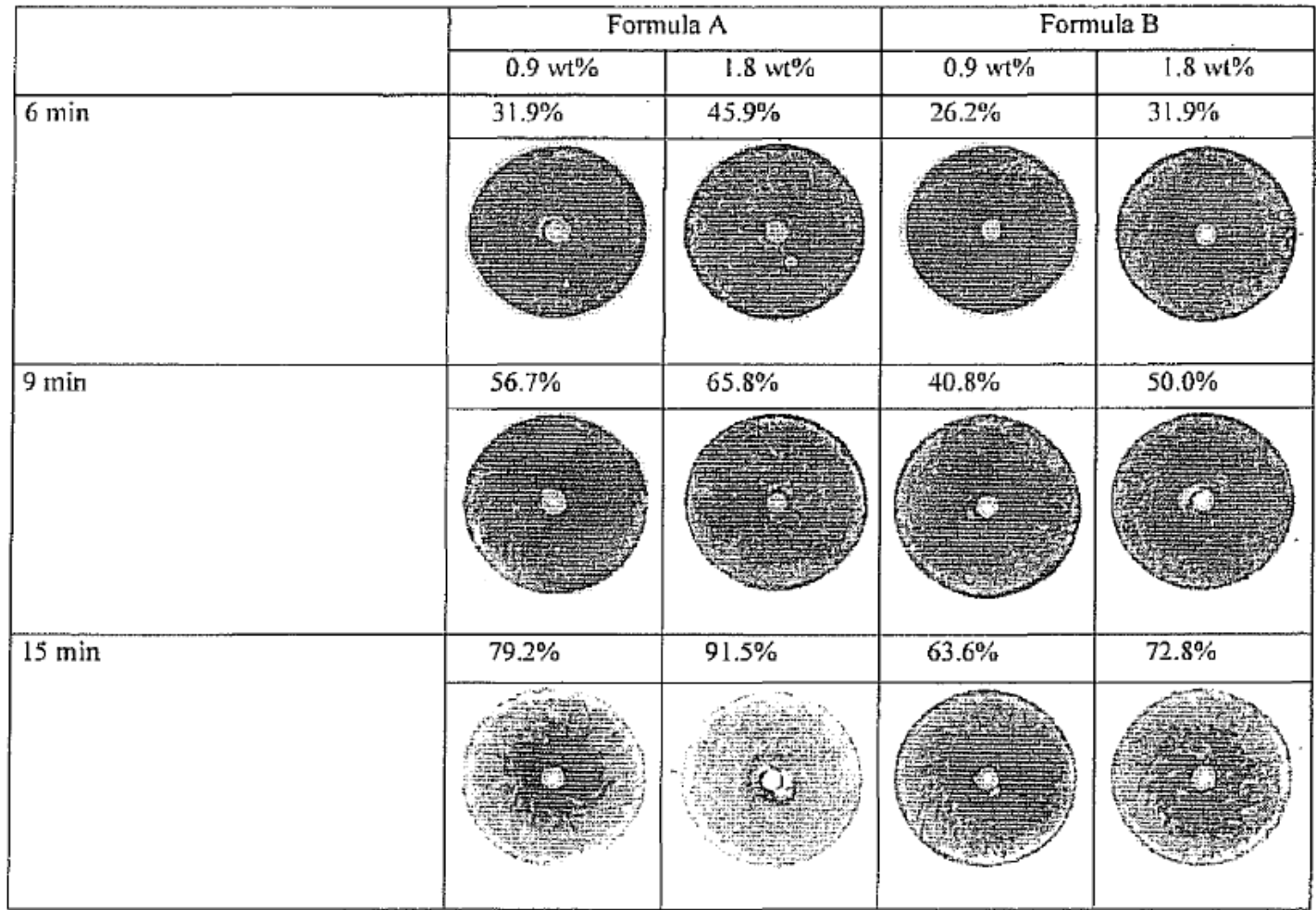

perform the experimental design on 16 responses with two repetitions, taking the mean value twice for the two last trials.

Resutts on solution concentration $\mathrm{C}$ and time $\mathrm{t}$. The second part of the experimental design shows the sensitivity of the test. It is performed on aged soil with two solutions (formulas A and B) having two different concentrations and for three different cleaning times. Cleaning solution concentrations and cleaning times are supposed to have a great influence on soil removal. Two formulae, having the same surfactant system but differing in the composition of the alkaline builder, are used to study the test sen-

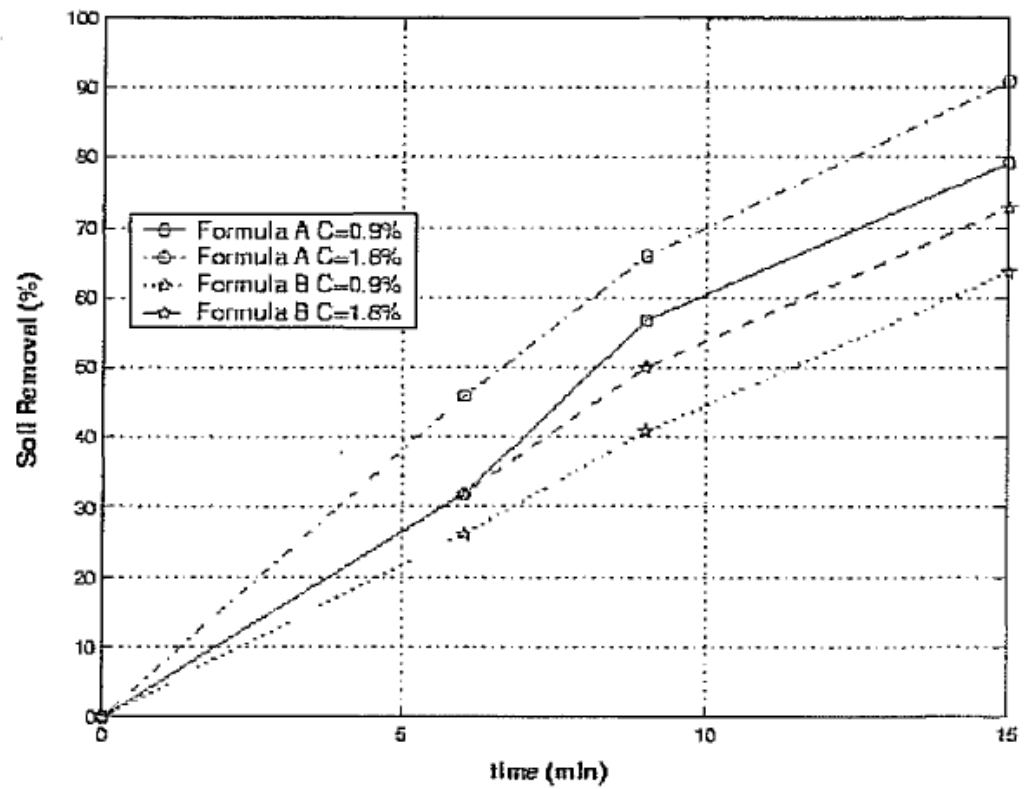

FIG. 3. Percentage of removed soil as a function of cleaning time for formulas $A$ and $B$ at two concentrations 
sitivity with the considered parameters. Formula A contains STPP and sodium pentahydrated metasilicates. Formula B contains STPP and sodium carbonate.

(i) Results for sail removal. Results (from using an agitation speed of $150 \mathrm{rpm}$ ) are shown in Table 7 and Figure 3 . Both formulae were tested at 0.9 and $1.8 \% \mathrm{w} / \mathrm{w}$, with cleaning times of 6,9 , and $15 \mathrm{~min}$. The reproducibility was calculated on repeated measurements, with a standard deviation of $1.5 \%$.

Results on pH and conductivity (Table 3). Cleaning baths had the same $\mathrm{pH}$ and concluctivity values for a given solution and concentration whatever the cleaning time. The "after cleaning" results are therefore mean values of the three cleaning baths.

Discussion on the effect of physicochemical parameters (temperature, agitation, and $p H$ ). Temperature and agitation were tested with the experimental design tool. A rotation speed change from 150 to $250 \mathrm{rpm}$ had a great effect on soil removal, almost twice as much as a $10^{\circ} \mathrm{C}$ increase in temperature. Concerning $\mathrm{pH}$, the higher the $\mathrm{pH}$ value, the better the soil removal (from a 6 up to a $12 \%$ increase). Formula B contains sodium carbonate; its $\mathrm{pH}$ does not vary much with concentration $(11.11 \pm 0.01$ and $11.15 \pm 0.01$ for 0.9 and $1.8 \% \mathrm{w} / \mathrm{w}$, respectively), whereas the $\mathrm{pH}$ of formula $\mathrm{A}$ is 11.96 and 12.17. Nevertheless, the increase in soil removal is similar (around 10\%) for both formulae when the concentration is doubled. This proves that $\mathrm{pH}$ is not the only parameter that influences cleaning; surfactants and synergies between surfactants and builders may play a major role.

The results show clearly that (i) the higher the solution concentrations, the better the soil removal efficiency, and (ii) the longer the cleaning time, the better the soil removal efficiency.

This new test exhibits high sensitivity. To compare cleaning solution efficiencies with precision, the test must be run with the chosen soil for a time lasting between 10 and 15 min. Shorter times give similar low percentage values $(<50 \%)$, and longer times lead to almost completely clean plates $(>90 \%$ ), whatever the detergent solution tested. Temperature, solution concentration, and rotation speed must be adequately chosen to show the differences among the tested solutions. In addition, a meaningful illustration of the results can be kept by the imprint of the cleaned plates.

\section{ACKNOWLEDGMENTS}

The authors thank the De La Vigie Company for financial support. They also thank Akzo Nobel Company for supplying the surfactant samples.

\section{REFERENCES}

1. Lawrence, A., The Mechanisis of Detergency, Cht'm. Ind. (London) t: 1764 (1961).

9. Küüssmann, H., and R. Bercovici, Detergency at Low T Lsing Combinations of Nonionic Surfactants and Mediunt-Chain Alcohols. Tenside Surf. Deterg. 30:99 (1993).

3. Morris, V.L., and D. Arthur, The Aerospace Industry: Regula- tory lmpacts on the Use of Solvent, Met. Finish. 93:20 (1995).

4. Ranade, M.B., Adhesion and Removal of Fine Particles of Surfaces, Aerosol Sci. Terhnol. 7:161 (1987).

5. Karlsson, C.A.C., M.C. Wahlgren, and A.C. Traedgaard, The Removal of $\beta$-Lactoglobulin from Stainless Steel Surfaces at High and Low Temperature as Influenced by the Type and Concentration of Cleaning Agent, J. Food Process Eng. 21:485 (1998).

6. Gomez Herrera, C., Detergencia. Sus Principales Mecanismos, Grasas Aceiles 47:419 (1996).

7. Prieto, N.E., W. Lilienthal, and P.L. Tortorici, Correlation Between Spray Cleaning Detergency and Dynamic Surface Tension of Nonionic Surfactants, J. Am. Oil Chem. Soc. 73:9 (1996).

8. Sado, G., and M.-C. Sado, Les plants d'expérientes, Afnor Editions, Paris, 1991, p. 211.

9. Ax L.C., S.K Misra and R.O. Sköld, Performance and recycling studies of alkaline metal cleaners, Tenside Surf. Deterg. 36:114 (1999).

10. Wüstneck, R, and G. Wasow, Studies on Surfactant Interaction, Tenside Sutrf. Deterg. 33:130 (1996).

11. Băckström, K, and S. Engström, Removal of Triglycerides from Hardsurfaces by Surfactants: An Ellipsometry Study, J. Am. Oil Chem. Sor. 65.412 (1988).

12. Hilgers, T., T. Bluhm, and H. Kruessmann, Untersuchung zur Bedeutung der Penetration als Physikalisch-cemuscher Faktor fuer die Wasch- und Reinigungswirkung, Tenside Surf. Deterg. 33:37 (1996).

13. Peterson, D., Industrial Lubricants, Cleaning Processes, and Waste Minimization, Precis. Cleaning 3:51 (1995).

14. Lebart, D.B., Alternatives for the Heat Treat Shop, Metal Heal Treating (Jan.-Feb.):21 (1995).

15. Krupers, M., Cleanability of Surfaces-How to Describe Coatings Pollution Characteristics and Cleaning Performance, Eur. Coat. J. 10:36 (2000).

16. Mittal, K, Surface Contamination-Concepts and Concerns, Precis. Cleaning $3: 17$ (1995).

17. Innes, W.P., Metal Cleaning, Met. Fïnish. 92:113 (1994).

18. Gauntt, D.L., K.G. Clark, D.J. Hirst, and C.R. Hegedus, A Soil Resistant Treatment for Low Gloss Coating, J. Coat. Technol. 63:25 (1991).

19. Gruss, B., Cleaning and Surface Preparation, Met. Finish. 93:26 (1995).

20. Kuhn, A.T., Is It Clean? Testing for Cleanliness of Metal Surfaces, Met. Finish. 91:25 (1993).

21. Jones, W.C., Testing Surfaces for Cleanliness, Met. Finish. 3:13 (1985).

22. Spring, S., Metal Cleaning, Reinhold Publishing, New York, 1963. 